\title{
PENGARUH ARUS KAS, PERBEDAAN LABA AKUNTANSI DAN LABA FISKAL TERHADAP PERSISTENSI LABA Nurul Fadhila
}

Prodi Akuntansi, Fakultas Ekonomi, Institut Manajemen Koperasi, Indonesia ${ }^{1}$ nurulfadhila18@ gmail.com ${ }^{1}$

\begin{abstract}
Abstrak
Latar belakang: Belakang ini dunia usaha sedang mengahadapi krisis keuangan yang cukup hebat akibat dari dampak adanya pandemi Covid-19.

Tujuan penelitian: Menganalisis dan mendapatkan bukti apakah arus kas, perbedaan laba akuntansi dan laba fiskal berpengaruh terhadap persistensi laba perusahaan pada PT. XYZ.

Metode penelitian: Metode penelitian yang digunakan pada penelitian ini adalah metode kuantitatif, yang betujuan untuk mengumpulkan, mengelolah, menguji, dan menganalisa suatu data yang berupa angka-angka untuk mengetahui pengaruh arus kas dan perbedaan laba akuntansi dan laba fiskal terhadap persistensi laba.

Hasil penelitian: Menurut hasil uji simultan F didapatkan hasil signifikasi sebesar 0.016 yang lebih rendah dari 0.05 yang artinya variabel independen (rasio intensitas modal, arus kas bebas dan manfaat) berpengaruh dengan variabel devenden.

Kesimpulan: Berdasarkan hasil penelitian maka arus kas operasi berpengaruh positif dan signifikan terhadap persistensi laba. Artinya, bahwa semakin tinggi arus kas operasi suatu perusahaan maka akan persistensi laba perusahaan juga akan meningkat. Perbedaan laba akuntansi dan laba fiskal berpengaruh positif signifikan terhadap persistensi laba, yang artinya semakin tinggi nya perbedaan antara laba akuntansi dan laba fiskal maka semakin rendahnya persistensi laba suatu perusahaan.
\end{abstract}

Kata kunci: Arus Kas, Aktivitas Operasi, Perbedaan Laba Akuntansi, Laba Fiskal, Persistensi Laba

\begin{abstract}
Background: Recently, the business world is facing a fairly severe financial crisis as a result of the impact of the Covid-19 pandemic.

Research purposes: Analyzing and obtaining evidence of whether cash flow, accounting profit differences and fiscal profit have an effect on the persistence of company profits at PT. XYZ.

Research methods: The research method used in this study is a quantitative method, which aims to collect, manage, test, and analyze data in the form of numbers to determine the effect of cash flows and differences in accounting and fiscal profits on earnings persistence.

Research results: According to the results of the simultaneous $F$ test, a significance result of 0.016 is obtained which is lower than 0.05, which means that the independent variables (capital intensity ratio, free cash flow and benefits) have an effect on the dividend variable.

Conclusion: Based on the results of the study, operating cash flow has a positive and significant effect on earnings persistence. This means that the higher the operating cash flow of a company, the persistence of company profits will also increase. The difference between accounting profit and fiscal profit has a significant positive effect on earnings persistence, which means:

it means that the higher the difference between accounting profit and fiscal profit, the lower the persistence of a company's profit.

Keywords: Cash Flow, Operating Activities, Accounting Profit Differences, Fiscal Profit, Earnings Persistence
\end{abstract}

Diterima: 26-11-2021; Direvisi: 29-11-2021; Disetujui: 14-01-2022

\section{PENDAHULUAN}

Belakang ini dunia usaha sedang mengahadapi krisis keuangan yang cukup hebat akibat dari dampak adanya pandemi Covid -19. Keadaan ini mengakibatkan banyak perusahaan yang mengalami kerugian bahkan sampai gulung tikar. Keadaan ini pada akhirnya memaksa perusahaan yang masih bertahan untuk tetap bertahan untuk menjaga 
kelangsungan hidupnya dengan bersaing dengan perusahaan lain. Untuk dapat bersaing dengan perusahaan lain maka perusahaan membutuhkan dana atau modal yang dapat diperoleh dari investor ataupun kreditur. Dana tersebut dapat diperoeh apabila perusahaan mendapatkan kepercayaan dari para investor maupun kreditur. Kepercayaan itu dapat diperoleh jika perusahaan dapat menunjukan kinerja perusahaan yang baik.

Kinerja perusahaan yang baik salah satunya dapat dilihat pada laba perusahaan yang diperoleh setiap tahunnya. Pelaporan keuangan adalah salah satu cara perusahaan untuk mengiformasikan kondisi keuangan dari hasil kegiatan operasi selama periode tertentu kepada berbagai pihak yang berkepentingan seperti, investor, kreditor, pemerintah, dan pembuat kebijakan. Selain itu, pelaporan keuangan juga menggunakan informasi arus kas untuk ukuran kinerja perusahaan.

Menurut Kieso (2010:1244) tujuan laporan arus kas yang utama adalah memberikan informasi tentang penerimaan dan pembayaran kas perusahaan selama suatu periode. Dan tujuan kedua adalah untuk menyediakan informasi kas dasar tentang operasi perusahaan, investasi, dan pendanaan.

Informasi tentang laba merupakan salah satu informasi yang terdapat di dalam laporan keuangan. Informasi yang mempunyai kaitan dengan laba mempunyai peranan terpenting dalam laporan keuangan, karena informasi yang berkaitan dengan laba (earnings) mempunyai peranan yang sangat penting bagi pihak-pihak yang berkepentingan terhadap suatu perusahaan. Laba biasa digunakan untuk menjadi dasar dalam pengambilan keputusan untuk investasi, pemberian kompensasi, bonus, sebagai pengukur kinerja manajemen, dan penentuan besarnya penghasilan kena pajak. Oleh karena itu, laba yang bekualitas diperlukan dalam pengambilan keputusan ekonomi. Laba yang berkualitas adalah laba yang mencerminkan kelanjutan laba (Sustainable earnings) di masa depan yang disebut dengan persistensi laba (Penman, 2001).

Laba yang dilaporkan menjadi dasar dalam menetapkan pajak. Dalam penetapan ini sering terjadinya perbedaan antara laba akuntansi dan laba fiskal. Perbedaan ini disebabkan karena adanya perbedaan tujuan masing-masing laba dalam pelaporan laba. Besarnya perbedaan laba akuntansi dengan laba fiskal dianggap sebagai dasar kualitas laba.

Persistensi laba akuntansi merupakan revisi pada laba akuntansi yang diharapkan di masa yang akan datang (Djamaludin, 2008:55). Besarnya revisi laba akuntansi ini akan menunjukkan tingkat persistensi laba.

Persistensi laba merupakan salah satu karateristik relevansi laba, maka beberpa informasi dalam perbedaan laba akuntansi dan laba fiskal dapat mempengaruhi persistensi laba.

Menurut Hanlon (2005) persistensi laba ditentukan oleh komponen akrual dan arus kas yang terdapat di dalam laba saat ini yang memiliki sifat sementara dan permanen. Sedangkan menurut penelitian Meythi (2006) menjelaskan bahwa arus kas tidak berpengaruh terhadap persistensi laba, dan menurut Sri Wineh (2008) menjelaskan bahwa arus kas operasi dapat berpengaruh terhadap persistensi laba.

Faktor lain yang memperngaruhi persistensi laba selain arus kas adalah perbedaan laba akuntansi dan laba fiskal. Perbedaan laba akuntansi dan laba fiskal secara negatif berpengaruh signifikan terhadap persistensi laba, yang artinya bahwa semakin besar selisih laba akuntandi dan laba fiskal maka semakin rendah persistensi laba perusahaan tersebut (Wijayanti, 2006). Perbedaan laba akuntansi dengan laba fiskal secara umum dikelompokkan pada perbedaan permanen (permanent differences) dan perbedaan sementara atau waktu (temporary or timing differences).

Saat ini perusahaan PT. XYZ masih membuat pembukuan ganda yaitu laporan keuangan akuntansi dan laporan keuangan fiskal. Perusahaan tidak perlu membuat 
laporan keuangan ganda untuk memenuhi tujuan dari laporan keuangan akuntansi dan laporan keuangan fiskal. Tetapi, ketika perusahaan akan membuat laporan keuangan fiskal maka akan terlebih dahulu melakukan rekonsiliasi terhadap laporan keuangan komersial.

Rekonsisliasi fiskal merupakan penyesuaian yang dilakukan kepada laporan keuangan komersial berdasarkan ketentuan perpajakan, sehingga didapat laba fiskal. Karenanya, adanya perbedaan pada dasar penyusunan dalam perhitungan laba menurut laporan keuangan komersial dengan laporan keuangan perpajakan dapat menyebabkan perbedaan pada jumlah antara penghasilan sebelum pajak (laba akuntansi) dengan penghasilan kena pajak (laba fiskal).

Perbedaan laba akuntansi dan laba fiskal dapat mewakili kebebasan manajemen dalam proses akrual, maka menurut Yulianti (2004) banyak peneliti yang menggunakannya sebagai indikator manajemen laba dalam menilai kualitas laba. Joss (2000) membuktikan bahwa hubungan negatif antara laba dengan return saham pada perusahaan yang mempunyai perbedaan besar antara laba akuntansi dan laba fiskal sebagai bukti adanya manajemen laba. Sedangkan pada penelitian Nissim (2004) membuktikan rasio laba akuntansi terhadap laba fiskal dapat memprediksi pertumbuhan laba untuk lima tahun kedepan, dan mempunyai hubungan kuat dengan return saham di masa yang akan datang.

Objek penelitian yang dipilih dalam penelitian ini adalah perusahaan Informasi Teknologi. Dipilihnya perusahaan ini karena perusahaan tersebut menyelenggarakan pembukuan atau menyusun laporan keuangan komersial berdasarkan Standar Akuntansi Keuangan (SAK) yang berlaku di Indonesia dan menyusun laporan keuangan fiskal berdasarkan peraturan perundang-udangan perpajakan yang berlaku di Indonesia.

\section{METODE PENELITIAN}

Metode penelitian yang digunakan pada penelitian ini adalah metode kuantitatif, yang betujuan untuk mengumpulkan, mengelolah, menguji, dan menganalisa suatu data yang berupa angka-angka untuk mengetahui pengaruh arus kas dan perbedaan laba akuntansi dan laba fiskal terhadap persistensi laba.

Penelitian ini bertempat di Penelitian ini dilaksanakan di Perseroan Terbatas (PT) XYZ yang merupakan perusahaan Informasi Teknologi yang beralamat di Perkantoran Tujuh Jl. Tebet Raya 7 Blok A 1-2, Tebet Barat, Kecamatan Tebet, Kota Jakarta Selatan, Daerah Khusus Ibukota Jakarta.

Teknik pengumpulan data yang digunakan sehingga dapat mendukung perolehan informasi untuk penyusunan penelitian ini, yaitu sebagai berikut :

1. Penelitian Langsung (Field Resech)

Penelitian langsung adalah studi lapangan dengan melakukan peninjauan secara langsung untuk mendapatkan data-data yang diperlukan dalam penyusunan penelitian.

a. Observasi (Observation)

Observasi adalah teknik pengumpulan data dengan cara mengamati langsung terhadap objek yang diteliti agar mendapatkan bukti-bukti yang dapat mendukung dan melengkapi hasil penelitian.

b. Dokumentasi (Dokumentation)

Dokumentasi adalah teknik pengumpulan data dengan cara mengadakan pencatatan dan pengumpulan data yang diidentifikasi dari dokumentasi yang terdapat kaitan dengan masalah yang diteliti.

c. Wawancara (Interview) 
Wawancara merupakan teknik pengumpulan data dengan cara tanyajawab yang dilakukan dengan objek yang sedang diteliti.

2. Studi Pustaka (Library Research)

Studi pustaka adalah mengumpulkan data dari beberapa bahan pustaka (referensi) yang relevan dan mempelajari yang berkaitan dengan masalah yang dibahas pada penelitian.

Metode yang digunakan untuk menganalisis data dan menguji hipotesis pada penelitian ini yaitu menggunakan statistik deskriptif dan metode analisis regresi berganda. Sebelum data dianalisis dengan regresi berganda, maka dilakukan terlebih dahulu uji asumsi klasik, maka dilakukan terlebih dahulu uji asumsi klasik yang terdiri dari uji normalitas, uji multikolinieritas, uji autokorelasi, dan uji heteroskedasitas sebelum melakukan uji hipotesis. Penelitian ini menggunakan bantuan dari perangkat lunak SPSS untuk menganalisis data.

\section{HASIL DAN PEMBAHASAN}

\section{Statistik Deskriptif}

Nilai Arus Kas terendah (minimum) adalah -26.443 .973 .819 yang diperoleh PT. XYZ pada tahun 2016, sedangkan nilai tertinggi (maximum) adalah 20.497.478.985 diperoleh PT. XYZ pada tahun 2019. Rata-rata (mean) dari Arus Kas adalah 1.864.012.036,60 dengan nilai standar deviasi sebesar 19.398.840.291,50. Variabel Beban Pajak Tangguhan memiliki nilai terkecil (minimum) sebesar 478.296.806 yang diperoleh PT. XYZ pada tahun 2016 ,sedangkan nilai tertinggi (maximum) adalah 5.441.154.927 pada tahun 2019. Ratarata (mean) dari Beban Pajak Tangguhan adalah 2.248.437.921,80 dengan nilai standar deviasi sebesar 1.922.658.349,25.

Variabel Total Aset memiliki nilai terkecil (minimum) sebesar 2.907.425.950 yang diperoleh PT. XYZ pada tahun 2020,dan nilai terbesar (maximum) adalah 131.444.714.260 diperoleh pada tahun 2019. Rata-rata (mean) dari Total Aset adalah 63.861.516.018,00 dengan nilai standar deviasi sebesar 46.269.528.224,06. Variabel Laba Akuntansi Sebelum Pajak memiliki nilai terkecil (minimum) sebesar 1.626.612.396 yang diperoleh PT. XYZ pada tahun 2020, dan nilai terbesar (maximum) adalah 22.988.531.786 diperoleh pada tahun 2019. Rata-rata (mean) dari Laba Akuntansi Sebelum Pajak adalah 6.278.719.033,60 dengan nilai standar deviasi sebesar 9.347.928.356,18. Koperasi Mitra Usaha membuat laporan keuangan sebagai bentuk pertanggungjawaban pengurus kepada anggota koperasi. Laporan keuangan merupakan hasil akhir yang telah dicapai dari kegiatan usaha dalam satu periode akuntansi. Melalui laporan keuangan Koperasi Mitra Usaha akan menyediakan informasi yang dapat dipercaya dalam pengambilan keputusan yang bermanfaat bagi anggota koperasi. Maka, laporan keuangan harus disajikan sesuai dengan pedoman akuntansi yang berlaku sehingga informasi yang disajikan akurat, dapat dipahami dan dapat diperbandingkan.

\section{Hasil Uji Asumsi Klasik}

a) Uji Normalitas

Hasil uji kolmogorov smirnov di atas, di dapat nilai p-value (asymp.sig) 0,200 dimana nilai tersebut lebih dari 0,05 . Pengujian akan menolak Ho jika p-value $<\alpha$ (10\%). Hasil pengujian menunjukkan p-value lebih dari $\alpha(10 \%)$ maka residual telah berdistribusi normal.

b) Uji Heteroskedastistas

Hasil dari scatterplot tersebut dapat dilihat bahwa data tidak membentuk suatu pola tertentu dan titik-titik data tidak hanya mengumpul di atas atau di bawah angka 0 
saja melainkan menyebar di atas dan di bawah. Jadi, dapat disimpulkan bahwa tidak ada heterokedastisitas pada data residual.

c) Uji Autokolerasi

Berdasarkan hasil uji autokorelasi, dapat dilihat bahwa nilai Durbin Watson sebesar 2,205. Terlihat bahwa nilai Durbin Watson berada pada daerah tidak menolah H0. Dalam hal ini kita dapat membuat kesimpulan dengan melihat nilai 2,205 yang lebih mendekati nilai 4-dU, maka cenderung akan menerika Ho dibandingkan menolaknya. Sehingga dapat disimpulkan bahwa tidak terdapat autokorelasi.

d) Uji Multikolinieritas

Berdasarkan hasil uji multikolinieritas, dapat dilihat bahwa nilai VIF lebih kecil dari standari nilai VIF 10 dan nilai tolerance lebih besar dari standar nilai tolerance 0,10 . Antara lain variabel arus kas operasi dengan nilai tolerance nya sebesar 0,931 dan nilai VIF nya sebesar 1,074, variabel perbedaan laba akuntansi dan laba fiskal nilai tolerance nya sebesar 0,931 dan nilai VIF nya sebesar 1,074 . Sehingga dapat disimpulkan bahwa tidak terdapat multikolinearitas atau korelasi yang tinggi antara variabel independen.

\section{Hasil Uji Hipotesis}

\section{a) Pengaruh Arus Kas (X1) terhadap Persistensi Laba (Y) Hasil Uji t}

Berdasarkan hasil uji t,nilai thitung 3,128 dengan signifikansi t sebesar 0,041. Dengan menggunakan n sebanyak 5, diperoleh nilai df (degree of freedom) sebanyak 3 , maka nilai ttabel diperoleh sebesar 2,353. Nilai thitung sebesar 3,128 lebih besar daripada nilai ttabel sebesar 2,353. Sedangkan jika dilihat dari nilai signifikansi yang diperoleh sebesar 0,041 lebih kecil dari 0,10. Sehingga dapat disimpulkan bahwa Ho ditolak, sehingga Hipotesis yang menyatakan "terdapat pengaruh positif yang signifikan antara Arus Kas terhadap Persistensi Laba" terbukti kebenarannya.

\section{Hasil Koefisien Regresi}

Berdasarkan hasil hitungan regresi linier sederhana diperoleh nilai koefisien regresi untuk variabel Arus Kas (X1) sebesar 0,263, dengan nilai konstanta sebesar 5788612591,382. Hasil regresi tersebut menunjukkan bahwa variabel Arus Kas (X1) secara linier mempunyai pengaruh positif terhadap Persistensi Laba sebesar 0,263, yang dapat diartikan bahwa semakin meningkat Arus Kas maka Persistensi Laba (Y) akan mengalami peningkatan juga.

\section{Hasil Koefisien Determinasi}

Berdasarkan hasil uji koefisien determinasi, diketahui bahwa nilai $\mathrm{R}$ Square sebesar 0,298. Hal ini berarti bahwa Persistensi Laba dipengaruhi oleh Arus Kas sebesar 29,8\% dan sisanya $71.2 \%$ dipengaruhi faktor lainnya.

b) Pengaruh Perbedaan Laba Akuntansi dan Laba Fiskal (X2) terhadap Persistensi Laba (Y)

\section{Hasil Uji t}

Berdasarkan hasil uji t (X2), nilai t hitung 3,409 dengan signifikansi t sebesar 0,070. Dengan menggunakan $\mathrm{n}$ sebanyak 5, diperoleh nilai df (degree of freedom) sebanyak 3, maka nilai ttabel diperoleh sebesar 2,353. Nilai thitung sebesar 3,409 lebih besar daripada nilai ttabel sebesar 2,353. Sedangkan jika dilihat dari nilai signifikansi yang diperoleh sebesar 0,070 lebih kecil dari 0,10. Sehingga dapat disimpulkan bahwa Ho ditolak, sehingga Hipotesis yang menyatakan "terdapat pengaruh positif yang signifikan antara Perbedaan Laba Akuntansi dan Laba Fiskal terhadap Persistensi Laba" terbukti kebenarannya.

\section{Hasil Koefisien Regresi}


Berdasarkan hasil perhitungan regresi linier sederhana diperoleh nilai koefisien regresi untuk variabel Perbedaan Laba Akuntansi dan Laba Fiskal (X2) sebesar 13945327220,245, dengan nilai konstanta sebesar 7636491873,072. Hasil regresi tersebut menunjukkan bahwa variabel Perbedaan Laba Akuntansi dan Laba Fiskal (X2) secara linier mempunyai pengaruh positif terhadap Persistensi Laba sebesar 13945327220,245, yang artinya semakin meningkat Perbedaan Laba Akuntansi dan Laba Fiskal (X2), maka Persistensi Laba (Y) akan semakin meningkat juga.

\section{Hasil Koefisien Determinasi}

Berdasarkan hasil uji koefisien determinasi, diketahui bahwa nilai $\mathrm{R}$ Square sebesar 0,281. Hal ini berarti bahwa Persistensi Laba dipengaruhi oleh Perbedaan Laba Akuntansi dan Laba Fiskal sebesar 28,1\% dan sisanya 71,9\% dipengaruhi faktor lainnya.

c) Pengaruh Arus Kas (X1) dan Perbedaan Laba Akuntansi dan Laba Fiskal (X2) terhadap Persistensi Laba (Y)

Hasil Uji F

Nilai Fhitung sebesar 10,810 dan sig sebesar 0,053. Dengan menggunakan df (degree of freedom) yaitu df $1=2$ dan df2 $=2$, diperoleh Ftabel sebesar 9,55. Hal ini menunjukkan bahwa nilai Fhitung 10,810 > Ftabel 9,55, sedangkan hasil signifikansi diperoleh nilai sebesar $0,053<0,10$. Sehingga hipotesis yang menyatakan "terdapat pengaruh positif yang signifikan antara Arus Kas dan Perbedaan Laba Akuntansi dan Laba Fiskal terhadap Persistensi Laba" dapat diterima.

\section{Hasil Koefisien Determinasi}

Diketahui bahwa nilai R Square sebesar 0,447. Hal ini berarti bahwa 44,7\% Persistensi Laba dipengaruhi oleh variabel Arus Kas dan Perbedaan Laba Akuntansi dan Laba Fiskal, sedangkan sisanya 55,3\% dipengaruhi oleh variabel lainnya yang tidak diteliti dalam penelitian ini.

\section{Pembahasan Hasil Analisis Data}

\section{Pengaruh Arus Kas Terhadap Persistensi Laba}

Berdasarkan analisis statistik di atas dalam penelitian ini bahwa H1 diterima dan dapat disimpulkan bahwa variabel arus kas operasi diperoleh nilai thitung sebesar 3,128 dan signifikasi sebesar 0,041. Jika di bandingkan dengan nilai ttabel diperoleh sebesar 2,353, maka thitung > ttabel dan sig < 0,10. Maka hal ini menunjukkan bahwa H1 diterima, yang artinya bahwa arus kas berpengaruh positif dan signifikan terhadap persistensi laba pada perusahaan informasi teknologi tempat penguji meneliti. Arus kas dapat mempengaruhi persistensi laba karena terdapat indikator dari komponen-komponen yang ada di dalam arus kas operasi itu sendiri seperti, penyusutan aset tetap, piutang, persediaan, pajak dibayar dimuka, aset, biaya yang masih harus di bayar, hutang, dan kewajiban imbalan pasca kerja. Laporan arus kas (cash flow) menjadi indikator untuk menilai kegiatan operasional pada masa lalu untuk merencanakan aktivitas investasi dan pembiayaan di masa depan. Selain itu laporan arus kas menggambarkan tentang penggunaan uang (kas) yang terdiri dari 3 bagian aktivitas yaitu investasi, operasi dan pendanaan. Sehingga sangat perlu bagi sebuah perusahaan untuk mengerti mendalam tentang hal ini. Jika dilihat secara luas tujuan dan fungsi laporan ini, adalah memberikan semua informasi tentang penerimaan dan pengeluaran yang sesuai dengan Prinsip Standar Akuntansi Keuangan (PSAK) 2, yang dimana ada tambahan mengenai aktivitas pendanaan menjadi alat pembayaran yang dimiliki perusahaan yang siap dipakai untuk investasi dan kegiatan operasional perusahaan kapanpun dibutuhkan, baik yang tersimpan di dalam perusahaan dan di bank yang selalu siap digunakan. Oleh sebab itu laporan arus kas menjadi salah satu faktor penting agar kedepannya sebuah perusahaan dapat memiliki laba yang persisten. Dari hasil penelitian ini dapat disimpulkan bahwa semakin tinggi arus kas operasi suatu perusahaan maka akan meningkatkan persistensi laba perusahaan 
tersebut. Hasil penelitian ini mendukung hasil penelitian (Asma, 2013) dan Dewi (2015) yang menyakatan bahwa arus kas berpengaruh positif terhadap persistensi laba. Tetapi hasil penelitian ini berbeda dengan hasil penelitian Meythi (2006) yang menyatakan bahwa arus kas tidak mempengaruhi persistensi laba.

\section{Pengaruh Perbedaan Laba Akuntansi dan Laba Fiskal dengan Proksi Beban Pajak Tangguhan terhadap Persistensi Laba}

Dari hasil pengujian statistik yang telah dilakukan diatas, diperoleh bahwa beban pajak tangguhan berpengaruh secara signifikan terhadap terhadap persistensi laba, dengan nilai signifikan sebesar 0,070 ( $\mathrm{sig}<0,10$ ). Maka artinya perbedaan laba akuntansi dan laba fiskal bernilai positif berpengaruh signifikan terhadap persistensi laba, atau dengan kata lain semakin besarnya perbedaan antara laba akuntansi dan laba fiskal maka akan menunjukkan persistensi laba yang semakin rendah, dan dengan demikian $\mathrm{H} 2$ dapat diterima.

Beban pajak tangguhan dan total aset merupakan indikator yang dapat mempengaruhi perbedaan laba akuntansi dan laba fiskal terhadap persistensi laba. Perbedaan antara laba akuntansi dan laba fiskal berpengaruh terhadap persistensi laba, karena laba yang ada di laporan keuangan mengukur keuntungan perusahaan yang berasal dari laba fiskal atau laba setelah pajak. Perbedaan antara laba akuntansi dan laba fiskal dapat digunakan untuk menilai kebijakan manajemen dalam proses akrual yang berkaitan dengan mengestimasi nilai depresiasi dan pengakuan penghasilan. Meskipun besar kecilnya ukuran perusahaan tidak dapat menjelaskan tentang perbedaan antara laba akuntansi dan laba fiskal, akan tetapi perbedaan laba akuntansi dan laba fiskal tetap menjadi salah satu faktor yang dapat dipertimbangkan oleh perusahaan untuk mendapatkan laba yang persisten.

Hasil pengujian ini mendukung hasil penelitian terdahulu yang dilakukan oleh (Annisa \& Kurniasih, 2017) yang menjelaskan perbedaan laba akuntansi dan laba fiskal berpengaruh secara positif dan signifikan terhadap persistensi laba.Menurut Resmi (2009) perbedaan dimasukkan sebagai koreksi positif apabila:

1. Pendapatan menurut fiskal lebih besar daripada menurut akuntansi atau suatu penghasilan diakui menurut fiskal tetapi tidak diakui menurut akuntansi.

2. Biaya atau pengeluaran menurut fiskal lebih kecil daripada menurut akuntansi atau suatu biaya atau pengeluaran tidak diakui menurut fiskal tetapi diakui menurut akuntansi.

Menurut Resmi (2009) perbedaan dimasukkan sebagai koreksi negatif apabila :

1. Pendapatan menurut fiskal lebih kecil daripada menurut akuntansi atau suatu penghasilan tidak diakui menurut fiskal (bukan objek pajak) tetapi diakui menurut akuntansi.

2. Biaya atau pengeluaran menurut fiskal lebih besar daripada menurut akuntansi atau suatu biaya atau pengeluaran diakui menurut fiskal tetapi tidak diakui menurut akuntansi.

3. Suatu pendapatan telah dikenakan pajak penghasilan bersifat final.

Dari paparan di atas maka, dapat disimpulkan bahwa laba akan lebih besar di laporan keuangan fiscal.

\section{KESIMPULAN}

Berdasarkan hasil penelitian dan pengujian yang telah dilakukan, dapat disimpulkan bahwa : 
1. Arus kas operasi berpengaruh positif dan signifikan terhadap persistensi laba. Artinya, bahwa semakin tinggi arus kas operasi suatu perusahaan maka akan persistensi laba perusahaan juga akan meningkat.

2. Perbedaan laba akuntansi dan laba fiskal berpengaruh positif signifikan terhadap persistensi laba, yang artinya semakin tinggi nya perbedaan antara laba akuntansi dan laba fiskal maka semakin rendahnya persistensi laba suatu perusahaan.

\section{BIBLIOGRAFI}

Ahsani, M. V. B. F., \& Maslichah, M. H. (2017). Pengaruh Aliran Kas Operasi Dan Perbedaan Antara Laba Akuntansi Dengan Laba Fiskal Terhadap Presistensi Laba (Studi Empiris Pada Perusahaan Manufaktur Yang Terdaftar Di Bursa Efek Indonesia). Jurnal Ilmiah Riset Akuntansi, 6(02).

Annisa, R., \& Kurniasih, L. (2017). Analisis Pengaruh Perbedaan Laba Akuntansi Dengan Laba Fiskal Dan Komponen Laba Terhadap Persistensi Laba. Jurnal Akuntansi Dan Bisnis, 17(1), 61-75.

Aribowo, F., \& Tombilayuk, A. (2020). Pengaruh Laba Bersih Dan Komponen Arus Kas Terhadap Harga Saham Pada Perusahaan Sektor Infrastruktur, Utilitas, Dan Transportas Yang Terdaftar Di Bursa Efek Indonesia Periode 2017- 2019. Prima Ekonomika, 11(2), 60-81.

Asma, T. N. (2013). Pengaruh Aliran Kas Dan Perbedaan Antara Laba Akuntansi Dengan Laba Fiskal Terhadap Persistensi Laba. Jurnal Akuntansi, 1(1).

Barus, A. C. (2014). Analisis Faktor-Faktor Yang Mempengaruhi Persistensi Laba Pada Perusahaan Manufaktur Di Bursa Efek Indonesia. Jurnal Wira Ekonomi Mikroskil: Jwem, 4(2), 71-80.

Baridwan, Zaki. 2004. Intermediate Accounting Edisi 8. Yogyakarta. Bpfe-Yogyakarta

Brolin, A. R., \& Rohman, A. (2014). Pengaruh Book Tax Differences Terhadap Pertumbuhan Laba. Diponegoro Journal Of Accounting, 3(2), 74-86.

Chowijaya, A., Effendi, R., \& Wenny, C. D. (2014). Pengaruh Laba Akuntansi, Laba Fiskal, Dan Arus Kas Operasi Terhadap Persistensi Laba. Stie Multi Data Palembang, 1-12.

Fajri, A., \& Mayangsari, S. (2012). Pengaruh Perbedaan Laba Akuntansi Dan Laba Pajak Terhadap Manajemen Laba Dan Persistensi Laba (Vol. 12). Faculty Of Business And Economics, Trisakti University.

Nuraeni, R., Mulyati, S., \& Putri, T. E. (2018). Faktor-Faktor Yang Mempengaruhi Persistensi Laba (Studi Kasus Pada Perusahaan Property dan Real Estate Yang Terdaftar Di Bursa Efek Indonesia Tahun 2013- 2015). Accruals (Accounting Research Journal Of Sutaatmadja), 2(1), 82-112.

Mardiasmo. 2018. Perpajakan Edisi Terbaru 2018. Yogyakarta. Andi Yogyakarta.

Muljono, Djoko. 2006. Akuntansi Pajak. Yogyakarta. Andi Yogyakarta Prabowo,

Yusdianto. 2004. Akuntansi Perpajakan Terapan Edisi Revisi. Jakarta. Pt Gramedia Widiasarana Indonesia.

Prasetyo, B. H., \& Rafitaningsih, R. (2015). Analisis Book Tax Differences Terhadap Persistensi Laba, Akrual Dan Aliran Kas Pada Perusahaan Jasa Telekomunikasi. Jiafe (Jurnal Ilmiah Akuntansi Fakultas Ekonomi), 1(1), 27-32.

Suwandika, I. Made Andi And Astika, Ida Bagus Putra (2013)'Keuangan. Dasar Yang Berbeda Dalam Penyusunan Laporan Keuangan Tersebut Kemampuan Perusahaan Dalam Memperoleh Laba Tidak Dapat Terlepas Dari'. E-Jurnal Akuntansi Universitas Udayana, 5(1), 196-214.

Wijayanti, H. T. (2006). Analisis Pengaruh Perbedaan Antara Laba Akuntansi Dan Laba 
Fiskal Terhadap Persistensi Laba, Akrual, Dan Aliran Kas (Doctoral Dissertation, Universitas Gadjah Mada).

Windarti, E. R., \& Sulistiani, D. (2015). Pengaruh Book Tax Differences Dan Arus Kas Terhadap Pertumbuhan Laba. El Muhasaba: Jurnal Akuntansi (E-Journal), 6(1), $111-125$

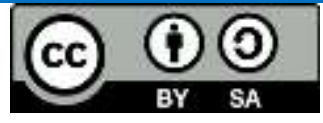

This work is licensed under a Creative Commons Attribution-ShareAlike 4.0 International License 